\title{
Heavy metal pollution in mine-soil-plant system in S. Francisco de Assis - Panasqueira mine (Portugal)
}

\author{
Carla Candeias ${ }^{a}$, Rita Melo ${ }^{a}$, Paula Freire Ávila ${ }^{b, *}$, Eduardo Ferreira da Silva ${ }^{\text {, }}$ Ana Rita Salgueiro ${ }^{\text {, }}$ \\ João Paulo Teixeira ${ }^{c}$ \\ ${ }^{a}$ University of Aveiro, Geosciences Department, GeoBioTec - Geobiosciences, Geotechnologies and Geoengineering Research Center, Campus de Santiago, 3810-193 Aveiro, \\ Portugal \\ ${ }^{\mathrm{b}}$ LNEG-National Laboratory of Energy and Geology, 4465-956 S. Mamede de Infesta, Portugal \\ ${ }^{\mathrm{c}}$ INSA - National Institute of Health, Environmental Health Department, Porto, Portugal
}

\section{A R T I C L E I N F O}

\section{Article history:}

Available online 29 July 2013

\begin{abstract}
A B S T R A C T
The active Panasqueira mine is a tin-tungsten ( $\mathrm{Sn}-\mathrm{W}$ ) mineralization hosted by metasediments with quartz veins rich in ferberite. The economic exploitation has been focused on wolframite, cassiterite and chalcopyrite. The mineralization also comprises several sulphides, carbonates and silver sulphosalts. The mining and beneficiation processes produces arsenic-rich mine wastes laid up in huge tailings and open air impoundments that are the main source of pollution in the surrounding area, once the oxidation of sulphides can result in the mobilization and migration of trace metals/metalloids from the mining wastes into the environment, releasing contaminants into the ecosystem.

A geochemical survey was undertaken, in order to investigate the environmental contamination impact on agricultural and residential soils in S. Francisco de Assis village due to the mining activities. Rhizosphere samples, vegetables (Solanum tubersum sava and Brassica olerácea L.) which constitute an important part of the local human diet), irrigation waters and road dusts were collected in private residences in S. Francisco de Assis village. According to the Ontario guidelines (Ministry of Environment, 2011), the Arsenic contents in the rhizosphere soils exceed 20 times the reference value for agricultural soils $\left(11 \mathrm{mg} \mathrm{kg}^{-1}\right)$. The result obtained showed that some edible plants frequently used in the region could be enriched in these metals/metalloids and may represent a serious hazard if consumed. The potatoes tend to have a preferential accumulation in the leaves and roots while in cabbages most elements have a preferential accumulation in the roots. An index of the risk for residents, due to ingesting of these metals/metalloids, by consuming vegetables grown around the sampling area, was calculated and the result indicates that the inhabitants of S. Francisco de Assis village are probably exposed to some potential health risks through the intake of arsenic, cadmium and also lead via consuming their vegetables.
\end{abstract}

(c) 2013 Elsevier Ltd. All rights reserved.

\section{Introduction}

The demand for ore comes from the beginning of the human existence and this activity plays a key role for human survival and development. Europe have an unquestionably importance in the world economy and mineral extraction plays an important role in the supply as also in the consumption of all groups of explored minerals. Portugal holds a rich and complex geology, which gives it a considerable mineral potential, although this sector only contributes with $1 \%$ for the Portuguese Gross Domestic Product (GDP).

The main mineral resources in Portugal are copper $(\mathrm{Cu})$, tin $(\mathrm{Sn})$, tungsten $(\mathrm{W})$, lithium $(\mathrm{Li})$, gold $(\mathrm{Au})$, iron $(\mathrm{Fe})$, zinc $(\mathrm{Zn})$, lead $(\mathrm{Pb})$, uranium $(U)$, coal, raw materials for construction and ornamental stones. Portugal is a country with a long mining tradition; it had

\footnotetext{
* Corresponding author. Tel.: +351 220400028.

E-mail address: paula.avila@lneg.pt (P.F. Ávila).
}

in the past and still has a strong mining activity. Land pollution due to mining activities is a major issue in many European countries and Portugal is not an exception (Santos Oliveira and Ávila, 1995, 2003; Valente and Leal Gomes, 1998; Bobos et al., 2006; Luís et al., 2009; Santos Oliveira et al., 2002; Ávila et al., 2005, 2008; Salgueiro et al., 2008; Grangeia et al., 2011; Candeias et al., 2011a,b; Ferreira da Silva et al., 2005; Antunes et al., 2002; Pinto et al., 2004; Carvalho et al., 2009, 2012; Gomes et al., 2010).

The extraction of metals from sulphide minerals usually results in large amounts of waste materials, tailings, and acid mine drainages, which often contain high concentrations of potentially toxic elements (PTE - As, Cu, Zn, Cd as an example) (Moore and Luoma, 1990; Boulet and Larocque, 1998; Jung, 2001; Naicker et al., 2003). Metals/metalloids can be dispersed downstream due to the weathering and erosion process of tailings. Thus, the extent and degree of heavy metal contamination around the mines varies depending upon geochemical characteristics and mineralization of tailings. 